\title{
Rapid loss of firn pore space accelerates 21 st century Greenland mass loss
}

\author{
J. H. van Angelen, ${ }^{1}$ J. T. M. Lenaerts, ${ }^{1}$ M. R. van den Broeke, ${ }^{1}$ X. Fettweis,${ }^{2}$ and \\ E. van Meijgaard ${ }^{3}$ \\ Received 1 March 2013; revised 18 April 2013; accepted 18 April 2013; published 23 May 2013.
}

[1] Mass loss from the two major ice sheets and their contribution to global sea level rise is accelerating. In Antarctica, mass loss is dominated by increased flow velocities of outlet glaciers, following the thinning or disintegration of coastal ice shelves into which they flow. In contrast, $\sim 55 \%$ of post- 1992 Greenland ice sheet (GrIS) mass loss is accounted for by surface processes, notably increased meltwater runoff. A subtle process in the surface mass balance of the GrIS is the retention and refreezing of meltwater, currently preventing $\sim 40 \%$ of the meltwater to reach the ocean. Here we force a high-resolution atmosphere/snow model with a mid-range warming scenario (RCP4.5, 1970-2100), to show that rapid loss of firn pore space, by $>50 \%$ at the end of the 21 st century, quickly reduces this refreezing buffer. As a result, GrIS surface mass loss accelerates throughout the 21 st century and its contribution to global sea level rise increases to $1.7 \pm 0.5 \mathrm{~mm} \mathrm{yr}^{-1}$, more than four times the current value. Citation: van Angelen, J. H., J. T. M. Lenaerts, M. R. van den Broeke, X. Fettweis, and E. van Meijgaard (2013), Rapid loss of firn pore space accelerates 21st century Greenland mass loss, Geophys. Res. Lett., 40, 2109-2113, doi:10.1002/grl.50490.

\section{Introduction}

[2] Arctic glaciers, ice caps, and ice sheets are melting at an alarming rate [Hanna et al., 2008; Van den Broeke et al., 2009; Rignot et al., 2011; Zwally et al., 2011; Lenaerts et al., 2013]. Especially notable is the demise of the Greenland ice sheet (GrIS), which lost an estimated $1000 \mathrm{Gt}$ in the warm summers of 2010 and 2011 alone and contributed $\sim 15 \%$ to $1992-2011$ global sea level rise [Rignot et al., 2011; Shepherd et al., 2012]. In Antarctica, mass loss is primarily caused by the acceleration of outlet glaciers in the Antarctic Peninsula and the Amundsen Sea sector of West Antarctica [Pritchard et al., 2012; Rignot et al., 2008], after thinning or disintegration of the ice shelves into which they flow. In contrast, glacier acceleration (i.e., ice discharge by calving) and meltwater runoff are about equally important in explaining post-1992 GrIS mass loss [Van den Broeke

Additional supporting information may be found in the online version of this article.

${ }^{1}$ Institute for Marine and Atmospheric Research Utrecht, Utrecht University, The Netherlands.

${ }^{2}$ Department of Geography, University of Liège, Liège, Belgium.

${ }^{3}$ Royal Netherlands Meteorological Institute, De Bilt, The Netherlands.

Corresponding author: J. H. van Angelen, Institute for Marine and Atmospheric Research Utrecht, Utrecht University, The Netherlands. (J.H.vanAngelen@uu.nl)

(C)2013. American Geophysical Union. All Rights Reserved. 0094-8276/13/10.1002/grl.50490 et al., 2009]. In the future, when the ice sheet retreats on land and loses contact with the ocean, runoff will become the dominant process of GrIS mass loss [Goelzer et al., 2012].

[3] The surface mass balance (SMB) of an ice sheet represents the complex balance between mass gain by accumulation (mainly snowfall) and mass loss by ablation (sublimation and runoff). Runoff is governed by the liquid water balance, the sum of water sources (rainfall and melt), and sinks (retention and refreezing). A key process for GrIS mass balance is meltwater retention and refreezing in the firn layer [Harper et al., 2012], currently preventing $42 \pm 4 \%$ of the rain and meltwater from reaching the ocean [Van Angelen et al., 2012]. Retention and refreezing are determined by the available pore space and temperature of the firn, the layer of compressed snow that covers the GrIS accumulation zone, representing $\sim 90 \%$ of the ice sheet surface [Ettema et al., 2009]. In the absence of suitable remote-sensing techniques, quantifying these processes requires the use of a coupled atmosphere/snow model [Reijmer et al., 2012].

\section{Methods}

[4] Here we use the regional atmospheric climate model RACMO2 [Van Meijgaard et al., 2008] (supporting information), interactively coupled to a multilayer snow model that explicitly treats the above processes and includes a prognostic albedo scheme based on snow grain size evolution [Kuipers Munneke et al., 2011; Van Angelen et al., 2012]. All model simulations are fully transient, which is important because of the long memory of up to several decades of the Greenland firn. When forced at the lateral boundaries and sea surface temperature by global reanalysis of the European Centre for Medium-range Weather Forecasts (ERA-40 from 1958 to 1978 and ERA-Interim from 1979 to present), RACMO2-fERA (RACMO2 forced by ERA) realistically reproduces the contemporary climate and SMB of the GrIS [Ettema et al., 2010], including post-2002 mass loss as measured by the twin satellites of the Gravity Recovery And Climate Experiment (GRACE [Rignot et al., 2011; Van den Broeke et al., 2009], Figure S1). The independent evaluation of GrIS accumulation (firn cover [Ettema et al., 2009]), melt (satellite [Fettweis et al., 2011]), and SMB (GRACE [Van den Broeke et al., 2009], supporting information) also provides robust support for the modeled retention and refreezing.

[5] For the contemporary and future climate (1971-2100), RACMO2 was forced with output of the HadGEM2-ES [Bellouin et al., 2011; Jones et al., 2011] general circulation model (GCM) (RACMO2-fHadGEM2). Out of the 27 GCMs used in the fifth Coupled Model Intercomparison Project (CMIP5), in the framework of the World Climate 


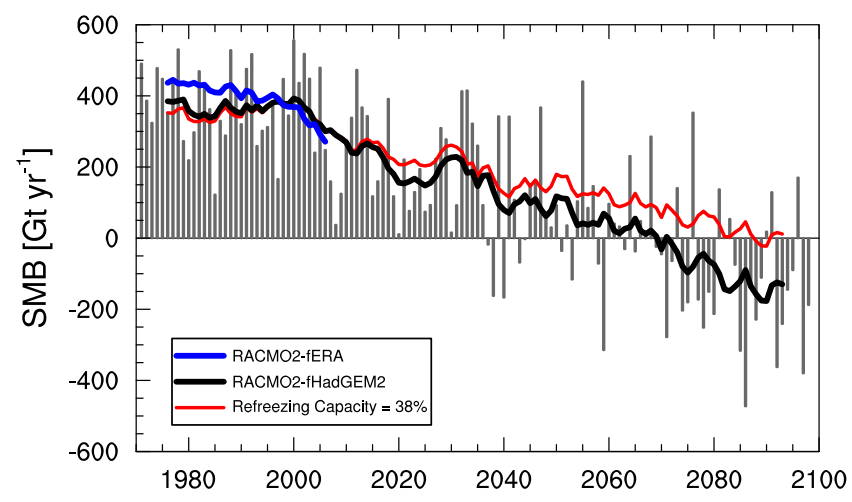

Figure 1. Annual SMB for RACMO2-fHadGEM2 (gray bars), with 11 year running average SMB for RACMO2-fERA (blue), RACMO2-fHadGEM2 (black), and RACMO2-fHadGEM2, assuming the refreezing capacity remains constant at $38 \%$ throughout the 21 st century (red). $104 \mathrm{Gt}$ is added to the RACMO2-fHadGEM2 SMB to correct for the SMB bias between the two simulations for the present day (1992-2011) (Table 1).

Research Programme [Taylor et al., 2007], HadGEM2-ES most realistically represents the present-day atmospheric circulation over the GrIS [Fettweis et al., 2012]. This is also valid for RACMO2-fHadGEM2 including precipitation distribution, seasonal cycle of $T_{2 m}$, and SMB components (supporting information).

[6] To assess 21 st century changes in GrIS SMB, we selected the Intergovernmental Panel for Climate Change RCP4.5 scenario; in this mid-range scenario, the global mean $\mathrm{CO}_{2}$ concentration stabilizes at $650 \mathrm{ppm}$ toward the end of the century resulting in an excess radiative forcing of $4.5 \mathrm{~W} \mathrm{~m}^{-2}$ relative to pre-industrial values [Moss et al., 2010]. Averaged over the 27 CMIP5 GCMs [Taylor et al., 2007], this scenario results in a $2.5 \pm 0.8 \mathrm{~K}$ increase in GrIS-average summer (JJA) $2 \mathrm{~m}$ temperature $\left(T_{2 m}\right)$ in 2079-2098 compared to 1992-2011 (Figure S6a). Note that the 21 st century $T_{2 m}$ change in HadGEM2-ES is very close to the ensemble mean. In RACMO2-fHadGEM2, the $T_{2 m}$ increase $(2.6 \mathrm{~K}$, Figure $\mathrm{S} 6 \mathrm{a})$ and especially its inter-annual variability ( 0.8 vs. $0.3 \mathrm{~K}$, Figure $\mathrm{S} 6 \mathrm{~b})$ are significantly larger than in the host model. This arises from a better resolved surface layer and a more realistic representation of snow albedo in RACMO2, which reacts sensitively to snow metamorphism at higher temperatures, introducing a positive feedback in the response of $T_{2 m}$ over snow [Van Angelen et al., 2012], leading to larger variability. The importance of a realistic representation of (near-)surface processes is further underlined by the weak correlation $\left(\mathrm{r}^{2}=0.15\right)$ between de-trended annual mean $T_{2 m}$ in HadGEM2-ES and RACMO2-fHadGEM2 averaged over the GrIS (Figure Sc).

\section{Results}

[7] In this combination of scenario and models, 10-year running average GrIS SMB turns negative around 2070 (Figure 1). Because solid ice discharge (iceberg calving) is a definite negative term in the ice sheet mass balance, $\mathrm{SMB}=0$ is sometimes interpreted as a tipping point beyond which an ice sheet cannot recover. The reason that this threshold is reached so soon is that the increase in snowfall on the GrIS (+53 Gt $\mathrm{yr}^{-1}$ in 2100 , Table 1) is by far insufficient to compensate the simultaneous increase in runoff

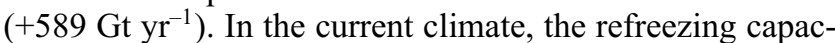
ity of the GrIS is $42 \pm 4 \%$ in RACMO2-fERA ( $38 \pm 4 \%$ in RACMO2-fHadGEM2), indicating that $42 \%$ of the total liquid water flux (rain plus melt, Figure $2 a$ ) is refrozen in the firn, the layer of compressed snow that covers the accumulation area of the ice sheet (Figure 2b). This efficient refreezing of meltwater confines runoff to a narrow band along the ice sheet margin (Figure 2c). In the current climate, runoff above $1500 \mathrm{~m}$ is only found in the southwest and to a lesser extent in the northeast GrIS; these are dry and sunny regions with relatively high summer melt rates, where the cold content of the shallow winter snowpack is quickly removed in spring.

[8] At the end of the 21 st century, the full ice sheet experiences melt on a seasonal basis (Figure $2 \mathrm{~d}$, note that rain is confined to elevations $<2000 \mathrm{~m}$ ). By that time, runoff is only significantly suppressed by refreezing at the highest elevations (Figure 2e) and the runoff zone has expanded far into the ice sheet interior, reaching elevations above $2500 \mathrm{~m}$ asl in the south, even crossing the ice divide (Figure $2 \mathrm{f}$ ). Total liquid water production increases strongly (rain and melt,

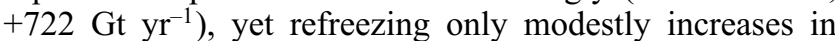

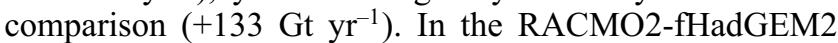
simulation, the refreezing capacity is reduced from $38 \%$ to $29 \%$ at the end of the 21 st century (Figure $3 \mathrm{c}$, blue line). This represents a $24 \%$ decrease in refreezing capacity in less than a century's time. The loss of refreezing capacity is concentrated in the lower accumulation area, and marks

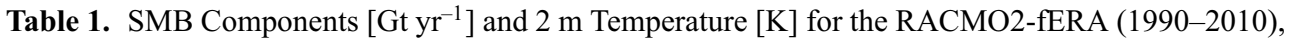
RACMO2-fHadGEM2 (1990-2010 and 2079-2098) and Differences Between the Two RACMO2fHadGEM2 Periods

\begin{tabular}{lcccc}
\hline & $\begin{array}{c}\text { RACMO2-fERA } \\
(1992-2011)\end{array}$ & $\begin{array}{c}\text { RACMO2-fHadGEM2 } \\
(1992-2011)\end{array}$ & $\begin{array}{c}\text { RACMO2-fHadGEM2 } \\
(2079-2098)\end{array}$ & Difference \\
\hline$T_{2 m}$ & $252.3 \pm 1.1$ & $253.3 \pm 1.3$ & $256.8 \pm 0.6$ & +3.5 \\
$T_{2 m}$ JJA & $266.4 \pm 1.0$ & $267.4 \pm 1.0$ & $270.0 \pm 0.7$ & +2.6 \\
SMB & $329 \pm 121$ & $225 \pm 144$ & $-233 \pm 179$ & -458 \\
Snowfall & $686 \pm 62$ & $731 \pm 77$ & $783 \pm 56$ & +53 \\
Rain & $53 \pm 12$ & $70 \pm 18$ & $144 \pm 35$ & +74 \\
Melt & $586 \pm 118$ & $791 \pm 147$ & $1439 \pm 212$ & +648 \\
Runoff & $368 \pm 95$ & $531 \pm 107$ & $462 \pm 62$ & +589 \\
Refreeze & $271 \pm 37$ & $329 \pm 53$ & $40 \pm 4$ & +133 \\
Sublimation & $41 \pm 4$ & $44 \pm 4$ & $29 \pm 2$ & \pm 3 \\
Refreeze cap. [\%] & $42 \pm 4$ & $38 \pm 4$ & -9 \\
\hline
\end{tabular}



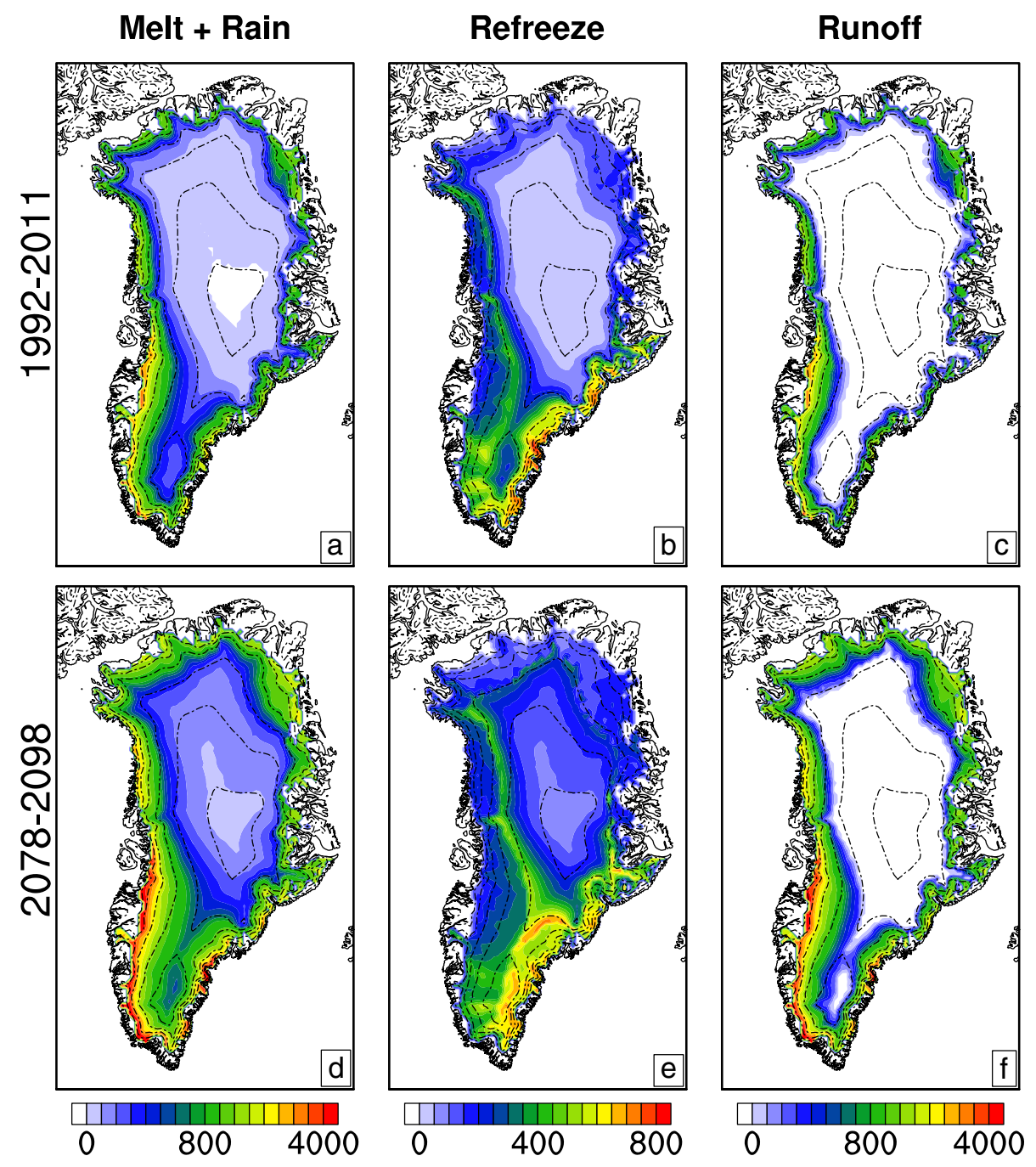

Figure 2. (a and d) Yearly averaged melt + rain, (b and e) refreezing, and (c and f) runoff (mm .w.e.) for 1992-2011 (Figures 2a-c) and 2079-2098 (Figures 2d-f) according to the RACMO2-fHadGEM2 simulation. Note the different scales. Dashed contours are $500 \mathrm{~m}$ elevation intervals.

the transformation of accumulation zone, with net annual surface mass gain, to ablation zone, where surface mass is lost on an annual basis. To demonstrate the impact of the reduction in refreezing capacity, we added to Figure 1 the hypothetical situation in which the refreezing capacity of the GrIS was to remain constant throughout the 21 st century. In that scenario, the SMB would remain positive for several decades longer.

[9] The reason for this loss of refreezing capacity is twofold. Upon refreezing in the cold firn sections of the ice sheet, the massive release of latent heat causes average firn temperature to increase by $4-5 \mathrm{~K}$ towards the end of this century. Locally this firn warming is projected to be as large as $18 \mathrm{~K}$ (Figure S7) at locations where refreezing and thus latent heat release increase most significantly (Figure 2e). More importantly, refreezing enhances firn densification by replacing air in the firn (pore space) with ice. The associated reduction of pore space prevents liquid water from being retained and refrozen when the winter cold wave penetrates downwards into the firn. Figure S8 demonstrates that pore space availability is the main limiting factor for refreezing; moreover, the temporary damping effect on mass loss of increased refreezing when melt and rain increase [Harper et al., 2012] is only short-lived. For Northeast Greenland, the transition of the firn layer to ice takes approximately two decades, for regions with higher precipitation and melt rates, the process is even faster $(\sim 10$ years $)$. From Figure S8, it can be deduced that approximately $80 \%$ of the initial pore space is used by additional refreezing. Figure 3 illustrates the dramatic loss $(50 \%)$ of pore space, in the top $20 \mathrm{~m}$ of the firn layer, toward the end of the century. During the last 20 years of the simulation, when the atmospheric warming ceases, the amount of pore space in the firn layer continues to decrease. This illustrates that the snowpack is still adjusting to the new climate, particularly in the colder and drier (northern and most elevated) parts of the ice sheet. The firn layer is thermally active for approximately the upper $10 \mathrm{~m}$ of the firn pack, on average. Therefore, as a safe limit, we included the top $20 \mathrm{~m}$ of the snow pack in our analysis. We also tested wether the inclusion of deeper layers would alter the results, but this was not the case.

[10] The increasing temperature and decreasing pore space in the upper (active) part of the firn layer, both caused by enhanced liquid water penetration, force a rapid decline 

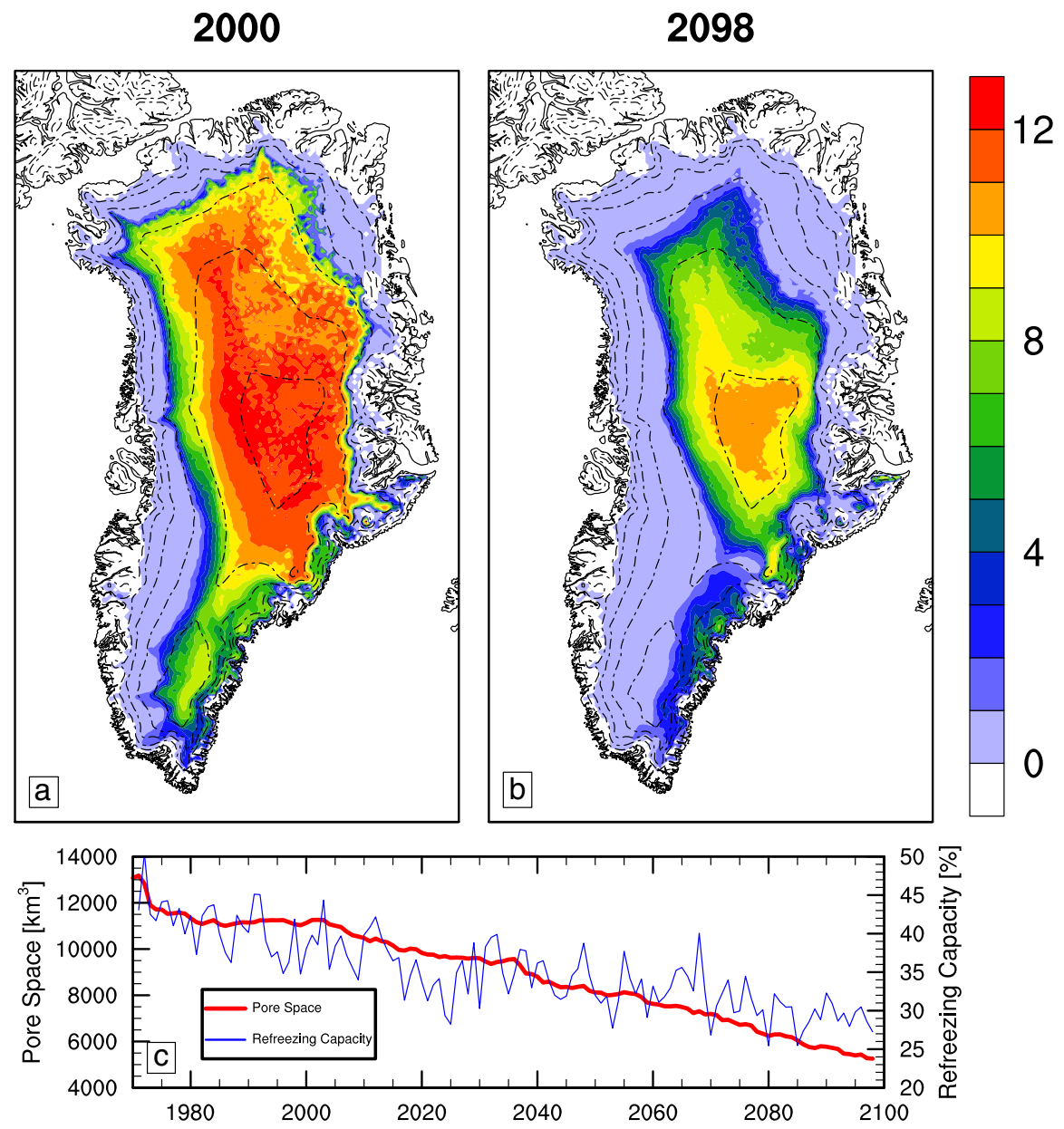

Figure 3. Pore space ([m], RACMO2-fHadGEM2) in the top $20 \mathrm{~m}$ of the snow pack averaged for the years (a) 2000 and (b) 2098. Dashed contours are $500 \mathrm{~m}$ elevation intervals. c) Total GrIS pore space in the top $20 \mathrm{~m}$ of the snow pack (red, left axis) and refreezing capacity (percentage of rain and meltwater that refreezes, blue, right axis).

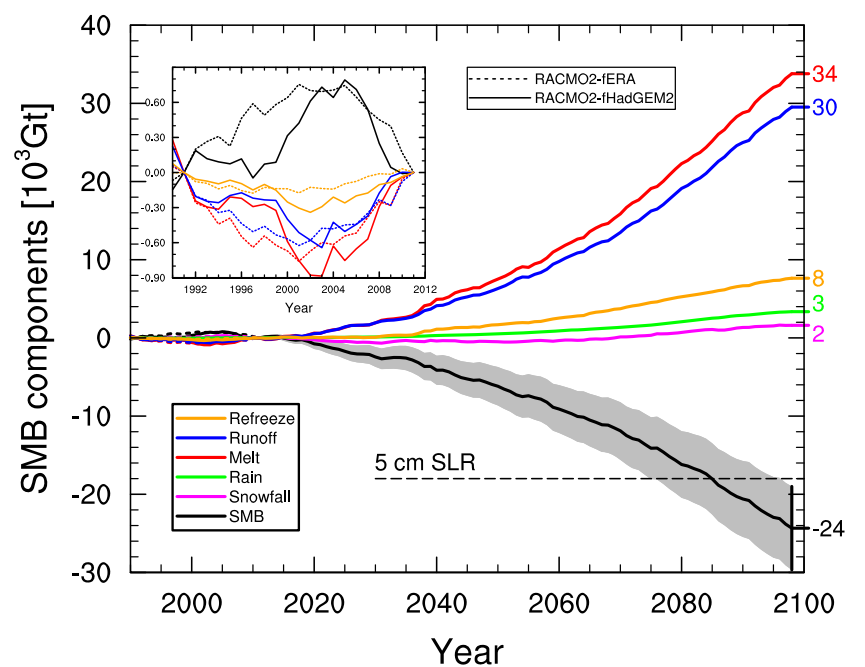

Figure 4. Cumulative SMB anomalies (black) and individual SMB components with respect to the 1992-2011 reference period for RACMO2 forced by HadGEM2-ES. The uncertainty is based on the present day uncertainty in GrIS SMB (i.e., $\pm 60 \mathrm{Gt}$ ). The inset expands the period 1992-2011 and compares RAMCO2-fHadGEM2 to RACMO2-fERA. Note that $3.6 \times 10^{3} \mathrm{Gt}$ is approximately equivalent to $1 \mathrm{~cm}$ of eustatic sea level rise. of the refreezing capacity of the GrIS. As a result, projected GrIS runoff continues to accelerate during the 21 st century (Figure 4, blue line), despite stabilizing temperatures. The cumulative runoff anomaly reaches $30 \pm 4 \times 10^{3} \mathrm{Gt}$ in 2100. The projected increase in snowfall compensates less than $10 \%$ of this, resulting in a projected end-of-century GrIS additional mass loss of $24 \pm 5 \times 10^{3} \mathrm{Gt}$, equivalent to $7 \pm 1 \mathrm{~cm}$ of eustatic sea level rise. The annual mass loss rate is $1.2 \mathrm{~mm} \mathrm{yr}^{-1}$ at the end of the century; because we consider anomalies with respect to 1992-2011, this must be added to the current GrIS sea level rise contribution $\left(\sim 0.4 \mathrm{~mm} \mathrm{yr}^{-1}\right)$ [Van den Broeke et al., 2011; Shepherd et al., 2012], leading to an annual rate of $1.7 \mathrm{~mm} \mathrm{yr}^{-1}$, more than four times the current value.

\section{Conclusions}

[11] We applied for the first time a fully transient highresolution simulation of a coupled atmosphere-snow model to the end of this century to assess the state of the Greenland firn and the feedback it has on the surface mass balance. The rapid loss of firn pore space in a warmer climate deteriorates the refreezing capacity of the GrIS; the refreezing buffer of the firn is removed after just several decades of enhanced melt. Although only one warming scenario (RCP 4.5) and one CMIP5 model is applied in this study, the results 
demonstrate the vulnerability of the Greenland ice sheet under this mid-range warming scenario in the 21 st century. A more rapid warming (i.e., RCP 8.5) would result in even faster loss of pore space in the Greenland firn. The increase in contribution from the GrIS to sea level rise as determined in this study is from surface processes alone, i.e., excluding ice dynamical changes. Moreover, the selected climate scenario is mid-range and the elevation-melt feedback has not been taken into account, the latter becomes more important the longer the projection and this will be incorporated in future work. As a result, this estimate of surface mass loss from the GrIS is deemed conservative.

[12] Acknowledgments. This work was supported by funding from the ice2sea programme from the European Union 7th Framework Programme, grant number 226375. Ice2sea contribution number 107.

[13] The Editor thanks Edward Hanna and an anonymous reviewer for their assistance in evaluating this paper.

\section{References}

Bellouin, N., et al. (2011), The HadGEM2 family of Met Office Unified Model climate configurations, Geosci. Model Dev., 4, 723-757, doi:10.5194/gmd-4-723-2011.

Ettema, J., M. R. Van den Broeke, E. Van Meijgaard, W. J. Van de Berg, J. L. Bamber, J. E. Box, and R. C. Bales (2009), Higher surface mass balance of the Greenland ice sheet revealed by high-resolution climate modeling, Geophys. Res. Lett., 36, L12,501, doi:10.1029/2009GL038110.

Ettema, J., M. R. Van den Broeke, E. Van Meijgaard, and W. J. Van de Berg (2010), Climate of the Greenland ice sheet using a high-resolution climate model, Part 1: Evaluation, The Cryosphere, 4, 511-527, doi: 10.5194/tc-4-511-2010.

Fettweis, X., M. Tedesco, M. R. Van den Broeke, and J. Ettema (2011), Melting trends over the Greenland ice sheet (1958-2009) from spaceborne microwave data and regional climate models, The Cryosphere, 5, 359-375, doi:10.5194/tc-5-359-2011.

Fettweis, X., B. Franco, M. Tedesco, J. H. V. Angelen, J. T. M. Lenaerts, M. R. V. D. Broeke, and H. Gallée (2012), Estimating Greenland ice sheet surface mass balance contribution to future sea level rise using the regional atmospheric climate model MAR, The Cryosphere Discuss., 6, 3101-3147, doi:10.5194/tcd-6-3101-2012.

Goelzer, H., P. Huybrechts, S. Raper, M. Loutre, H. Goosse, and T. Fichefet (2012), Millennial total sea-level commitments projected with the earth system model of intermediate complexity LOVECLIM, Environ. Res. Lett., 7, 045,401, doi:10.1088/1748-9326/7/4/045401.

Hanna, E., P. Huybrechts, and K. Steffen (2008), Increased runoff from melt from the Greenland ice sheet: A response to global warming, J. Climate, 21,331-341, doi:10.1175/2007JCLI1964.1.

Harper, J., N. Humphrey, W. T. Pfeffer, J. Brown, and X. Fettweis (2012), Greenland ice-sheet contribution to sea-level rise buffered by meltwater storage in firn, Nature, 491, 240-243, doi:10.1038/nature11566.
Jones, C. D., et al. (2011), The HadGEM2-ES implementation of CMIP5 centennial simulations, Geosci. Model Dev., 4, 543-570, doi: 10.5194/gmd-4-543-2011.

Kuipers Munneke, P., M. R. Van den Broeke, J. T. M. Lenaerts, M. G. Flanner, A. S. Gardner, and W. J. Van de Berg (2011), A new albedo parameterization for use in climate models over the Antarctic ice sheet, J. Geophys. Res., 116, D05,114, doi:10.1029/2010JD015113.

Lenaerts, J. T. M., J. H. V. Angelen, M. R. V. den Broeke, A. S. Gardner, B. Wouters, and E. V. Meijgaard (2013), Irreversible mass loss of Canadian Arctic archipelago glaciers, Geophys. Res. Lett., 40, 1-5, doi:10.1002/grl.50214.

Moss, R. H., et al. (2010), The next generation of scenarios for climate change research and assessment, Nature, 463, 747-756, doi:10.1038/nature08823.

Pritchard, H. D., S. R. M. Ligtenberg, H. A. Fricker, D. G. Vaughan, M. R. Van den Broeke, and L. Padman (2012), Antarctic ice-sheet loss driven by basal melting of ice shelves, Nature, 484, 502-505, doi:10.1038/nature 10968 .

Reijmer, C. H., M. R. V. D. Broeke, X. Fettweis, J. Ettema, and L. B. Stap (2012), Refreezing on the Greenland ice sheet: A comparison of parameterizations, The Cryosphere, 6, 743-762, doi:10.5194/tc-6-743-2012.

Rignot, E., J. L. Bamber, M. Van den Broeke, C. Davis, Y. Li, W. Van de Berg, and E. Van Meijgaard (2008), Recent Antarctic ice mass loss from radar interferometry and regional climate modelling, Nat. Geosci., 1, 106-110, doi:10.1038/ngeo102.

Rignot, E., I. Velicogna, M. R. Van Den Broeke, A. Monaghan, and J. T. M. Lenaerts (2011), Acceleration of the contribution of the Greenland and Antarctic ice sheets to sea level rise, Geophys. Res. Lett., 38, L05,503, doi:10.1029/2011GL046583.

Shepherd, A., et al. (2012), A reconciled estimate of ice sheet mass balance, Science, 338, 1183-1189, doi:10.1126/science.1228102.

Taylor, K. E., R. J. Stouffer, and G. A. Meehl (2007), A summary of the CMIP5 experiment design, World, 4, 1-33.

Van Angelen, J. H., J. T. M. Lenaerts, S. Lhermitte, X. Fettweis, P. Kuipers Munneke, M. R. Van den Broeke, E. Van Meijgaard, and C. J. P. P. Smeets (2012), Sensitivity of Greenland ice sheet surface mass balance to surface albedo parameterization: A study with a regional climate model, The Cryosphere, 6, 1175-1186, doi:10.5194/tc-6-11752012 .

Van den Broeke, M. R., J. L. Bamber, J. Ettema, E. Rignot, E. Schrama, W. J. Van de Berg, E. Van Meijgaard, I. Velicogna, and B. Wouters (2009), Partitioning recent Greenland mass loss, Science, 326, 984 doi:10.1126/science. 1178176

Van den Broeke, M. R., J. L. Bamber, J. T. M. Lenaerts, and E. Rignot (2011), Ice sheets and sea level: Thinking outside the box, Surv. Geophys., 27, pp. 1-11, doi:10.1007/s10712-011-9137-z.

Van Meijgaard, E., L. H. van Ulft, W. J. van de Berg, F. C. Bosveld, B. van den Hurk, G. Lenderink, and A. P. Siebesma (2008), The KNMI regional atmospheric climate model RACMO version 2.1, Tech. Rep. 302 .

Zwally, H. J., et al. (2011), Greenland ice sheet mass balance: Distribution of increased mass loss with climate warming; 2003-07 versus 1992-2002, J. Glaciol., 57, 88-102, doi:10.3189/002214311795306682. 